\title{
Communication Strategy Using Da'wah Assembly to Heal Traumatised Natural Disaster Victims in Palu City
}

Muhammad Khairil, ${ }^{+*}$ Raisa Alatas, ${ }^{\dagger}$ Dyah Fitria Kartika Sari, ${ }^{\dagger}$ and Mirfath $^{+}$

\section{Abstract}

This article discusses how Asybaalul Khairaat volunteers' make use of the trauma healing approach via $d a^{\prime}$ wah based communication strategy to tackle traumatised victims of natural disasters in a refugee camp at Palu, Indonesia. Traumatic events of natural disasters leave psychological impacts such as stress, and anxiety. In the study location, trauma healing programs are widely applied during the disaster and recovery process, with interpersonal exchanges used to increase self-motivation. Therefore, da'wah is one of the bases of the trauma healing process, provided by the Asybaalul Khairaat assembly group, which is supported by Alkhairaat scholars, such as HA. This technique aids in distributing and preaching religious values to the refugees in Alkhairaat schools. The purpose of this article, therefore, is to probe and describe the communication strategy of Asybaalul Khairaat volunteers. The qualitative method with a case study approach was used to analyse the data. At the orientation stage, they focused on the field survey, which allowed them to directly meet the victims or refugees and the initial distribution. Furthermore, humanitarian bonds were built with the attitude of positive mutual help which reflects true Islam. This was followed by the distributing of $d a ' w a h$ after the purchase of Islamic symbols. Finally, spontaneity and uniqueness emerged when Asybaalul Khairaat volunteers tried to demonstrate the right form of trauma healing linked to jihad in Islam by directly assisting in humanitarian activities.

Keywords: Communication Strategy; Da'wah Based Communication; Trauma Healing; Asybaalul Khairaat

\footnotetext{
${ }^{+}$Department of Communication Studies, Faculty of Social and Political Sciences, Tadulako University, City of Palu, Indonesia

${ }^{*}$ Corresponding Author, Email: mkhairil@untad.ac.id

(C) 2020 Khairil et al. This is an Open Access article distributed under the terms of the Creative Commons Attribution License (http://creativecommons.org/licenses/by/2.0), which permits unrestricted use, distribution, and reproduction in any medium, provided the original work is properly cited.
} 


\section{Introduction}

Natural disasters are naturally occurring events which creates a significant impact on the human populations on earth (Bystritsky, Vapnik, Maidment, Pynoos, \& Steinberg, 2000; Najarian, Goenjian, Pelcovitz, Mandel, \& Najarian, 2001; Penick, Powell, \& Sieck, 1976). In addition to casualties, it leaves survivors traumatised due to the loss of family members, and destruction of property (Harville, Jacobs, \& Boynton-Jarrett, 2015). According to Penick et al., 1976, natural disasters as traumatic events which tend to leave psychological disorders such as stress, tensions and anxiety on the victims. Therefore, trauma healing programs are widely applied during the disaster response process (Ajdukovic, 2004; Rahman, 2018; Walsh, 2007), in addition to material and spiritual assistance (Rokib, 2012).

Apart from trauma healing, communication strategies also help to overcome spiritual shock (Ulfa, 2013). An interpersonal approach is a personal two-way communication process which takes place and heals spiritual communication (Jordan, Masters, Hooker, Ruiz, \& Smith, 2014). The word "personal" is used to describe intended messages adequately and effectively conveyed to the communicant(Khairil, 2007).

This article discusses how Asybaalul Khairaat volunteers' utilise the trauma healing approach via da'wah based communication strategy to tackle traumatised victims of natural disasters in a refugee camp at Palu, Indonesia.

Furthermore, it also discusses how the concept of trauma healing is carried out in providing assistance to disaster victims, by providing the values of $d a^{\prime} w a h$ as a concept of interpersonal approach within a group (Bryant-Davis \& Wong, 2013). Religious preaching or da'wah become one of the examples of the concept of trauma healing provided by the Asybaalul Khairaat assembly group, and supported by Alkhairaat scholars. Religious preaching or $d a^{\prime} w a h$ is not a speech, rather it provides advice and guidance to the victims/refugees (Handayani, 2017). The $d a^{\prime}$ wah conducted by HA and his group is held at any time without any special conditions, or place, thereby allowing everyone to attend. This strategy is conducted in a creative and innovative way without being separated from its original purpose (Khairil, 2018).

The article begins by discussing the research methodology, followed by brief background information on the trauma healing approach based on the communication strategy of $d a^{\prime}$ wah to tackle the symptoms linked to trauma amongst victims of Palu. In the final section, it discusses how the volunteers of Asybaalul Khairaat apply this strategy.

\section{Research Methodology}

Based on the formulation of the problem and objectives, this study uses a qualitative method with a case study approach. It analyses the da'wah based communication strategy of Asybaalul Khairaat volunteers using the trauma healing approach on the victims of natural disasters in Palu. This study leads to a detailed and in-depth description of the problems regarding the portrayed condition and what actually had happened. The case study research is a qualitative approach which examines reallife cases through detailed and in-depth data collection of data entailing multiple sources of information such as interviews, audio-visual materials, observations, and documents (Creswell, 2015). This research was conducted at Alkhairaat Foundation of Palu, Central Sulawesi, with data obtained through observation and existing information.

Furthermore, purposive sampling was used to maximise the depth of the data. Primary data sources selection (informants) were carried out together with the collection process using snowball sampling technique (Moleong, 2014). This was conducted due to the lack of complete data regarding the number and characteristics of sources at the study site with adequacy by researchers.

Data analysis in this research begins with preparation and organisation using transcripts, or images such as photographs for analysis, with reduction through codes and summary 
processes. Finally, the data was presented in the form of charts, tables or discussion (Creswell, 2015). The triangulation technique with emphasis on different sources used to test its validity, especially on those with similarities (Moleong, 2014; Sutopo, 2002).

\section{Backdrop: Trauma Healing and $D a^{\prime}$ wah Based Communication Approach}

According to the American Psychological Association, trauma is an emotional response to an adverse event such as an accident or natural disaster (American Psychological Association, 2013). The Sidran Institute for Traumatic Stress Education \& Advocacy provides a broader definition of psychological trauma. Giller defined it as an individual feeling of overwhelm, emotion, cognitively, and physical experience or condition (Giller, 1999). Psychological trauma includes responses to accidents, natural disasters, crime, and death. The determination and occurrence of a traumatic impact depend on the individual. According to the American Psychological Association, trauma causes reactions in the form of mood swings, flashbacks (bad memories that are clearly remembered repeatedly), disturbed interpersonal relationships, even physical symptoms such as headaches and nausea in the long term (Fact News, 2018).

Consequences for mental health in the population is more significant in groups of people yet to experience it directly, with a lower disrupting risk on those that experience it directly (Harville et al., 2015).

Trauma on victims of natural disasters, should not be prolonged; therefore, therapy is required (Zoellner et al., 2018). Its healing is one of the primary needs of disaster victims to help them in the complete recovery process. Trauma healing is greatly required in Indonesia, which is a country prone to natural disasters ranging from floods, landslides, earthquakes, etc. Fear of disaster is a very common reaction experienced by the victims, with the emotional loss, insomnia, excessive vigilance, and flashbacks. Trauma healing is carried out through drug administration, or psychological therapy with the healing given to adults different from children (Hoskins, Duncan, Moskowitz, \&
Ordóñez, 2018). In children, it is conducted through several methods; the first is through the play therapy technique (Rahman, 2018).

Sarafino defined social support as an effort which leads to an increase in individual welfare (Sarafino, 1990). This is divided into verbal and non-verbal support types which provides information and spiritual or material assistance. It is also related to communication and interpreted as the process of delivering a process conducted by someone to another through social relations. From various definitions presented by experts, it is concluded that communication is the process of conveying symbols which contains the same meaning by someone to others with the intention to understand (Khairil, 2017). Therefore, to change the behaviour of traumatised victims, communication symbols in the form of verbal or non-verbal form are utilised (Effendy, 1991).

$D a$ 'wah is defined as a call, appeal or invitation. It is pronounced as mashdar in Arabic, while the verb form fi'il means to call or invite ( $D a^{\prime} a, Y^{\prime} a d^{\prime} u$, Da'watan) (Saputra, 2011). Therefore, Da'wah is a religious invitation to embrace, which basically bears a positive connotation with the substance which lies in the activity that commands amar ma'ruf and nahi mungkar (Saputra, 2011). It is a process used to invite people to do good, introduce and guide them to God, and teach amar and nahi munkar for the benefit of the world. Da'wah based communication is an invitation made by its communicators by employing verbal and non-verbal communication aimed at the good of the world(Khairil, 2018).

Being spiritual means having more ties to other worldly and psychological things rather than physical or material (Hasan, 2006; Shoukat \& Pulla 2017). Spirituality is an awakening or enlightenment in achieving life's purpose and meaning. It is an essential part of one's overall health and well-being ( Hasan, 2006; Shoukat \& Pulla, 2017). Religion is one of the most decisive factors in promoting the values and virtues of life in society through teachings as well as practices for humans and society (Zoellner et al., 2018). This perspective is built by the values, virtues, 
and principles of life which a person believes. It is formed through the learning process, which is passed by people throughout their life. Using this backdrop, this study shows how Asybaalul Khairaat volunteers' applied $d a^{\prime}$ wah based on the communication strategy through the trauma healing approach amongst the victims of natural disasters in Palu.

\section{The $D a^{\prime}$ wah Based Communication Strategy: A Vehicle to Healing Trauma}

In the orientation phase, the Asybaalul Khairaat volunteers focused on the field survey, which allowed them to directly meet the refugees in order to understand their basic needs and the initial distribution. This process was used to build the humanitarian bond by the volunteers with the firm attitudes of positive mutual help reflecting the values embedded in true Islam.

According to $\mathrm{HA}$, helping is always tied with humanity based on the Prophet's hadith. It is proper for every human to help those experiencing difficulties. This humanitarian basis made young people from Nabire, Papua to join Asybaalul Khairaat volunteers with different religious backgrounds.

Following the findings, at the exchangeexploratory stage, it appears that the victims or refugees started paying attention to the symbols brought by the volunteers, with the spread of Da'wah.

The obligation in the Islamic mission is to provide da'wah in the form of trauma healing. According to Wahyu Hidayat, the victims initially felt scared, which was clearly displayed by their aura and body language. However, at the arrival of the volunteers, they started showing extraordinary improvement in enthusiasm to face the struggles of life patiently. Although not continuously conveyed, the victims were reassured of assistance.

This is similar to what was explained by the theory of social penetration, which states that the development of relations moves from the most superficial to the deepest level. A larger number of interactions lead to a relaxed and carefree atmosphere. In the refugee camp of Palu, the volunteers built interwoven relationships by mingling with young men from Nabire, Papua baring differing religious beliefs, which indicates that both Muslims and nonMuslims have the ability to work together during humanitarian services to the society. The nonMuslims that cooperated with Asybaalul Khairaat did not make rejection efforts, despite deviations from the people, it always valued as unwise action contrary to human values.

When the volunteers tried to convey the pure form of trauma healing, namely jihad in Islam, by directly assisting humanitarian activities, spontaneity and uniqueness emerged. HA asserted that "jihad does not necessarily have to take up arms but also to seek knowledge, fight lust, earn a living, and help others. Whatever humans conduct in the form of goodness is a true form of jihad because good deeds are attributed to the worship of Allah. Therefore, the image of removing thorns on the road is a good deed in the sight of Allah, let alone feeding and helping people".

\section{Conclusion}

The aim of this research was to examine how volunteers of Asybaalul Khairaat used communication strategy through the inculcation of Islamic spirituality (jihad) to heal the traumatised victims of natural disaster at a refugee camp in Palu. This is descriptive research with limitations associated with the extent to which the traumatised victims were healed. Nonetheless, this perspective demonstrates that during disasters, it is the humanity that overshadows religions. Although several questions are yet to be answered, this research forms the basis for a future in-depth study as to how the volunteers of non-voluntary organisations conduct their selfless services to humanity.

\section{References}

Ajdukovic, D. (2004). Social Contexts of Trauma and Healing. Medicine, Conflict and Survival, 20(2), 120-135.

https://doi.org/10.1080/136236904200023471 7

American Psychological Association. (2013).

Recovering Emotionally from Disaster. 
Bryant-Davis, T., \& Wong, E. C. (2013). Faith to move mountains: Religious Coping, Spirituality, and Interpersonal Trauma Recovery. American Psychologist, 68(8), 675-684. https://doi.org/10.1037/a0034380

Bystritsky, A., Vapnik, T., Maidment, K., Pynoos, R. S., \& Steinberg, A. M. (2000). Acute Responses of Anxiety Disorder Patients after a Natural Disaster. Depression and Anxiety, 11(1), 43-44. https://doi.org/10.1002/(SICI)15206394(2000)11:1<43::AID-DA7>3.0.CO;2-D

Creswell, J. W. (2015). Penelitian Kualitatif dan Desain Riset (Ed Ke-3). Yogyakarta: Pustaka Pelajar.

Effendy, O. U. (1991). Radio, Siaran, Teori \& Praktek. Bandung: Mandar Maju.

Fact News. (2018). Trauma Healing Untuk Korban Gempa Lombok.

Giller, E. (1999). What Is Psychological Trauma?

Handayani, B. L. (2017). Aplikasi Nilai-Nilai Islam Dalam Wadah Kelompok Pengajian Muslimat Sebagai Upaya Recovery Pasca Bencana. In Menemukan Kembali Paradigma Pembangunan Islami (pp. 495-518). Jember: Jember University Press.

Harville, E. W., Jacobs, M., \& Boynton-Jarrett, R. (2015). When Is Exposure to a Natural Disaster Traumatic? Comparison of a Trauma Questionnaire and Disaster Exposure Inventory. PLOS ONE, 10(4), e0123632.

https://doi.org/10.1371/journal.pone.0123632

Hasan, A. W. (2006). Aplikasi Strategi dan Model Kecerdasan Spiritual (SQ) Rasulullah Di Masa Kini. Yogyakarta: IRCiSod.

Hoskins, D., Duncan, L. G., Moskowitz, J. T., \& Ordóñez, A. E. (2018). Positive Adaptations for Trauma and Healing (PATH), a pilot study of group therapy with Latino youth. Psychological Trauma: Theory, Research, Practice, and Policy, 10(2), 163-172.

https://doi.org/10.1037/tra0000285

Jordan, K. D., Masters, K. S., Hooker, S. A., Ruiz, J. M., \& Smith, T. W. (2014). An Interpersonal Approach to Religiousness and Spirituality: Implications for Health and Well-Being. Journal of Personality, 82(5), 418-431.

https://doi.org/10.1111/jopy.12072

Khairil, M. (2007). Pluralisme, Toleransi dan

Budaya Komunikasi Ummat Beragama. Jurnal Inspirasi MKDU Untad, (3), 25.

Khairil, M. (2017). The Transformation of the Symbolic Meaning of Radicalism in Acts of Terrorism Post-Conflict in Poso Central Sulawesi. International Conference on Democracy, Accountability and Governance, 282-289.

Khairil, M. (2018). Wahdah Islamiyah's CounterRadicalism Strategy Through The New Media Network in Da'wah Development Of Palu City. Al-Ulum, 18(2), 417-435.

https://doi.org/10.30603/au.v18i2.610

Moleong, L. J. (2014). Metodologi Penelitian Kualitatif. Bandung: Remaja Rosdakarya.

Najarian, L. M., Goenjian, A. K., Pelcovitz, D., Mandel, F., \& Najarian, B. (2001). The effect of relocation after a natural disaster. Journal of Traumatic Stress, 14(3), 511-526. https://doi.org/10.1023/A:1011108622795

Penick, E. C., Powell, B. J., \& Sieck, W. A. (1976). Mental Health Problems and Natural Disaster: Tornado Victims. Journal of Community Psychology, 4(1), 64-68.

https://doi.org/10.1002/15206629(197601)4:1<64::AID-

JCOP2290040103>3.0.CO;2-0

Rahman, A. (2018). Analisa Kebutuhan Program Trauma Healing Untuk Anak-Anak Pasca Bencana Banjir Di Kecamatan Sungai Puas Tahun 2018: Implementasi Manajemen Bencana. LPPM UMSB, XII(2), 1-6.

Rokib, M. (2012). The Significant Role of Religious Group's Response to Natural Disaster in Indonesia: the case of Santri Tanggap Bencana (Santana). Indonesian Journal of Islam and Muslim Societies, 2(1), 53-77.

Saputra, W. (2011). Pengantar Ilmu Dakwah. Jakarta: Raja Grafindo Persada.

Sarafino, E. P. (1990). Health Psychology. Singapore: John Willey \& Sons.

Shoukat, A., \& Pulla, V. R. (2017). Desert 
Dwellers' Meaning and Existence of Spirituality: Walsh, F. (2007). Traumatic Loss and Major A Gendered Case Study of Cholistan, Pakistan. Disasters: Strengthening Family and Community Space and Culture, India, 5(2), 32-46. https://doi.org/10.20896/saci.v5i2.278 Resilience. Family Process, 46(2), 207-227.

Sutopo, H. B. (2002). Metodologi Penelitian https://doi.org/10.1111/j.15455300.2007.00205.x

Kualitatif. Surakarta: Sebelas Maret University.

Ulfa, E. (2013). Intervensi Spiritual Emotional Freedom Technique untuk Menurunkan Gangguan Stres Pasca Trauma Erupsi Gunung Merapi. Journal of Educational, Health, and Zoellner, L., Graham, B., Marks, E., Feeny, N., Bentley, J., Franklin, A., \& Lang, D. (2018). Islamic Trauma Healing: Initial Feasibility and Pilot Data. Societies, 8(3), 47. https://doi.org/10.3390/soc8030047 Community Psychology (JEHCP), 2(1), 38-57. https://doi.org/http://dx.doi.org/10.12928/jehc p.v2i1.3743 